International Journal of Finance and Accounting (IJFA) FINANCIAL RE-ENGINEERING AND
FINANCIAL PERFORMANCE OF SACCO Emily Esokomi and Willys Otuya 


\title{
FINANCIAL RE-ENGINEERING AND FINANCIAL PERFORMANCE OF SACCOS
}

\author{
1*Emily Esokomi \\ ${ }^{1}$ Post graduate student: Masinde Muliro University of Science and Technology- Kenya \\ *Corresponding Authors Email: emilyesokomi@gmail.com \\ ${ }^{2}$ Willys Otuya \\ $\mathrm{PhD}$, Lecturer, Masinde Muliro University of Science and Technology -Kenya
}

\begin{abstract}
Purpose: The current study sought to establish the trends in financial re-engineering and financial performance of SACCOs and present existing knowledge gaps that need to be filled based on studies done in other contexts.

Methodology: The study adopted a desktop literature review method (desk study). This involved an in-depth review of studies related to financial re-engineering and its effects on financial performance of SACCOs. Three sorting stages were implemented on the subject under study that is financial reengineering and financial performance of SACCOs, in order to determine the viability of the subject for research. After an in-depth search into the top key words (financial strategies, financial innovation, financial reengineering and financial performance of SACCOs), the researcher arrived at 15 articles that were suitable for analysis.
\end{abstract}

Results: The study noted that from the survey, majority of the studies were based and cited most between the year 2012 and 2018, implying the relevance of the subject in the current decade. From the analysis, most of the publications on financial reengineering and financial performance of SACCOs, were from the renowned Journal published under various journal platforms. This is an indication of the credibility of the subject under review by many scholars. In addition, the survey provides evidence as to why the subject under review is of importance in the African context since majority of the studies under review were from the European and Asian regions. A trend analysis was conducted indicating that over the period the studies were researched. Financial reengineering and performance subject have been receiving the concerns by various authors. This was drawn from the upwards increasing trend in the subject of the study since 2012 to 2019. The survey likewise found that descriptive research design was the trending technique to survey studies on financial reengineering and performance. Majority of the studies from the analysis revealed a positive relationship between financial reengineering and financial performance of SACCOs.

Unique contribution to theory, practice and policy: Based on the survey findings, the study recommended that financial reengineering effect on financial performance in SACCOs is a maiden study that other authors from other parts can use to base future studies on. Findings from this study may be used to shape policy in the area of managing financial performance in SACCOs. Currently, the existing financial strategies are weak, not standard and not competitive since the competition from other related financial institutions is stiff. The findings would help to further develop an adaptive strategy for to step up in the competition in the financial sector. 
International Journal of Accounting and Finance (IJAF)

ISSN 2518 - 4113 (online)

Vol. 5, Issue 1, No. 2, pp 19 - 31, 2020

www.iprjb.org

Keywords: Financial strategies, financial innovation, financial reengineering, financial performance of SACCOs.

\subsection{INTRODUCTION}

Financial re-engineering involves the design, the development, and the implementation of innovative financial instruments and processes, and the formulation of creative solutions to problems in finance. The term "innovative" is used here to describe a solution that is non- trivial (Revathy \& Santhi, 2008). Innovative financial solutions may involve a new consumer type financial instrument, new security, such as money market preferred stock; a new process, such as the shelf registration process; or a creative solution to a corporate finance problem, such as the design of customized security arrangements for a project financing or a leveraged buyout.

Restructuring in the financial system has become a major component in the financial and economic environment all over the world. Further, restructuring has raised important issues for business decisions, government policy, and Foreign Direct Investment policy as well as for public policy formulation (Becheikh, Landry \& Amara, 2006). Hence, in recent times, companies have started restructuring their financial operations around their core business activities. A SACCO may grow internally, or externally. The objective of the organisation, in either case, is to maximize the wealth of the existing shareholders. Most corporate growth occurs by internal expansion, which takes place when an organisation's existing divisions grow through normal capital budgeting activities.

The definition of corporate financial reengineering distinguishes three types of activities. The first, securities innovation, involves the development of innovative financial instruments, including those developed primarily for consumer-type applications such as new types of SACCO accounts, new forms of mutual funds, new types of life insurance products, and new forms of residential mortgages (Onduko, 2013). Innovative financial instruments also include those developed primarily for corporate finance applications such as new debt instruments; options, futures, and other new risk management vehicles; new types of preferred stock; new forms of convertible securities; and new types of common equity instruments (Batiz \& Woldesenbet, 2006). The second branch of corporate financial engineering involves the development of innovative financial processes. These new processes reduce the cost of effecting financial transactions and are generally the result of legislative or regulatory changes (for example, the shelf registration process), or technological developments (electronic security trading). The third branch involves creative solutions to corporate finance problems. It encompasses innovative cash management strategies, innovative debt management strategies, and customized corporate financing structures such as those involved in various forms of asset-based financing.

Sacco's are recognised as critical avenues for economic growth worldwide. About a billion people are associated with cooperatives that make up ICA, a global umbrella organization that serves cooperatives worldwide. The International Cooperative Alliance (ICA), a vibrant, diverse cooperation sector is a major factor in the growth of these economies in many countries which have achieved economic development. In providing financial services to the poor, SACCOs plays an important role. They provide individuals, companies and team members with savings and credit services for growth opportunities. Sacco performs an active role of financial brokerage, particularly between urban and semi-urban to rural and net savers and net borrowers and ensures 
International Journal of Accounting and Finance (IJAF)

ISSN 2518 - 4113 (online)

Vol. 5, Issue 1, No. 2, pp 19 - 31, 2020

www.iprjb.org

the preservation of credit capital in the communities from which savings are mobilized (Onduko, 2013).

\subsection{Background of the Study}

Sacco is part of the Kenyan cooperative industry which over the years has influenced many Kenyans. The sector can be categorized as financial and non-financial cooperatives. The marketing of products or services from members such as milk, livestock coffee, tea, craft products and many similar cooperatives is dealt with by non-financial cooperatives. Financial cooperatives, on the other hand, provide cooperatives for Sacco, residential property and savings. The DTSs form part of the broad subsector of Sacco in Kenya, which includes the deposit and non-disposal take-over of Sacco Societies. Sacco Societies are also active.

Savings and Credit Cooperative Society (SACCO) is a member-owned financial cooperative whose primary objective is to mobilize savings and afford members access to loans on competitive terms as a way of enhancing their socio-economic well-being (Kamonjo, 2014). It is formed by people having a common bond. They are important form of financial intermediary, which over the years has played a vital role in the provision of financial services to their members (Bwana \& Mwakujonga, 2013). In Kenya, formal cooperatives started taking shape when European settlers formed the Lumbwa Cooperative Society in 1908. Currently, SACCOs are credited in the world over for improving peoples' social-economic status. SACCOs are responding gradually to the dynamic and competitive financial environment and are adopting new approaches to the original model. SACCOs movement in Kenya controls over Ksh 490 billion ( $\$ 5.5$ billion) in the form of assets and savings, an amount equivalent to $35 \%$ of the national budget.

Financial reengineering is used by financial institutions as a formidable strategic tool to outshine competition and is an essential means for the institutions to maintain their effectiveness and improve their performance in the market (Batiz \& Woldesenbet, 2006). In the current dynamic and competitive business environment, a firm must continuously develop products and product lines in order to satisfy the constantly changing needs and desires of customers and maximize its set objectives in terms of sales volume, market share and profitability (Grundiche, 2004). Elements of operations performance that include quality, speed, efficiency and flexibility are related to the firm's performance in product and process innovation (Kimani, 2016). Higher performance and continuing efforts in innovations boost organizational learning and improve the quality and speed of the operations. Therefore, innovation advancements and reengineering financial processes can be incorporated easily and any quality or design deficiencies can be overcome faster resulting in better performance (Coad \& Rao, 2008).

Product and services restructuring offer potential protection to a firm from market threats and competitors. Susman, Warren, Ding and Stites (2006) proved that product innovation had positive and significant link with financial performance. All financial innovation strategies are implemented using a few basic techniques such as increasing or reducing risk, pooling risk, swapping income streams, splitting income streams and connecting long-term obligation into short-term ones in SACCOs (Onduko, 2013). Innovation strategy is determinant of Sacco financial performance and provides additional insight into the indirect contribution of the individual dimensions of innovation strategies to Sacco performance. 


\subsection{LITERATURE REVIEW}

Revathy and Santhi (2008) assessed the financial reengineering effect on State Bank of India. The purpose of this study was to evaluate the state bank's economic performance. The secondary analysis data is the Balance Sheet (2008 to 2012). In order to analyze the data, the researcher applied ratio analysis. Based on the results of the data analysis, some suggestions have been provided. The study infringed that the bank could make a long way to better serve its stakeholders and can enhance it through the implementation of the suggestions of restructuring the financial department activities and operations.

Terziovski, Fitzpatrick and O'Neill (2003) conducted a research on the business process reengineering in the financial sector in Australia. A cross-sectional research report based on a survey questionnaire forwarded to BPR-implementing strategic business units within the Australian Financial Services sector. The study focused on the pro-active application of BPR as part of the organization's business strategies, together with the focus on key business processes for BPR's clients. The implications of these findings are that managers need consumers to re-engineer their core operations. The paper asserts that attitudes and culture change, extensive communication and resistance against change from middle management are the key obstacles for successful implementing BPR.

Khuzaimah (2011) aimed at assessing the impact of reengineering on corporate performance and finding out how business process reengineering can assist organizations implement innovative and strategic administrative changes in Malaysian Banks. Data from the primary source, evaluated through basic percentage analysis and regression analysis, were collected for this current research. The paper concludes that reengineering of business processes has become the instrument used to improve their current organizational performance by any corporate organization that seeks to achieve cost management strategies in its business and the environment.They proposed that reengineering processes remain effective tools that enable organizations to operate as effectively and efficiently as practicable. In order to achieve successful performance and long-term strategy for organisation's growth and performance, organisations should reengineer business processes.

Revathy and Santhi (2014) did a study of financial reengineering in Ashok Leyland Ltd in Hosur. Secondary data was collected between year 2009 and 2013 from the financial reports. Financial restructuring is becoming a key component of the world's financial and economic system. In the context of management decisions, government policies, and foreign direct investment policy, as well as for public policy implementation, industrial reorganisation has been important. In India, since 1991, domestic and international competition, competitiveness and the implementation of the Liberalisation Privatisation and Globalisation (LPG) have become increasingly subjected to Indian industries. Through capital recycling, businesses have now restructured their operations into their core business activities. However, this study was done in Ashok Leyland in India.

Shin and Jemella (2002) investigated during this study the most suitable BPR approaches for financial institutions. The case study involved the collection of primary data for the analzsis. Based on the case study of Chase Manhattan Bank, it was found that at providing guidance for BPR projects in financial institutions led to achievement of significant gains in efficiency. Chase BPR projects include four phases involving a broad range of activities: stimulation, concentration, 
inventing and initiation. Such efforts resulted in new products or services in addition to dramatically higher sales and operational costs, as can be seen in Chase BPR initiatives like e-fund disbursement cards and service charge reengineering.

Aregbeyen (2011) focused on the effect of business reengineering on the performance of First Bank in Nigeria. The performance was assessed in form of growth, profitability and financial development. The data was collected from the year 1986 to 2008. The regression analysis was done on the data. The results revealed that the process of reengineering the projects have a positive significance on the improvement of performance of except for its growth factor. The obliteration of the outdated practices and starting over in the practices in the bank processes was impactful to the development of the bank.

Eniola and Entebang (2015) aimed to assess the financing strategies of SME in Nigeria. The article conceptualized their financing challenges, sources of funding, the ways for exploiting innovative ways of improving funding through crowd-funding, and the need to provide an environmental regulatory framework that supports the growth and promotion of SMEs. One way of fostering economic development in Nigeria for small and medium-sized enterprising businesses to become increasingly important and irreplaceable is by boosting funding by crowdfunding. Nonetheless, it needs to be the government which will help crowd funding in Nigeria in a regulatory environment.

Ngure (2017) did an assessment on the effect of financial innovation on the performance of SACCOs. As of December 31, 2013, the population of the study was 56 SACCOs working and active in Nyeri County. The study employed a cross-sectional survey design and stratified methods used to evaluate the sample of 30 SACCOs. The study concludes that financial developments and the efficiency of SACCOs have an important relationship with telephone banking and internet banking as key drivers of the SACCO financial performance. The report recommends more development in mobile and Internet banking since the two-boost profitability in comparison with ATM banking.

Nyathira (2012) conducted a research with the goal to examine over a four-year period the effects of financial restructuring on the performance of commercial banks as key actors in the banking industry. Study results suggest that financial development actually contributes to the competitiveness of the banking sector, in particular that of the commercial banks. This is also positively linked to profitability in Kenya, as of 30 June 2012. The higher utilization of more efficient financial systems to replace less effective traditional systems is further supported.

Muteke, (2015) conducted a research study to examine whether SACCOs ' financial performance in Mombasa County is influenced institutional innovation, process innovation and product innovation. This research aimed to collect and analyze data on the financial performance of SACCOs in Mombasa Country on the basis of financial restructuring variables. The study populated 165 SACCOs in the county of Mombasa. A representative sample of 36 SACCOs was used in the study. The determination index demonstrated that 23.2\% of SACCOs in Mombasa County were influenced by financial innovation. The study found that the financial advancement of the SACCOs in Mombasa County is a predictor of the financial performance. The SACCOs in Mombasa County have made great use of all kinds of financial innovation and all have had a positive effect on their financial results. The study suggested that SACCO Management Boards 
International Journal of Accounting and Finance (IJAF)

ISSN 2518 - 4113 (online)

Vol. 5, Issue 1, No. 2, pp 19 - 31, 2020

www.iprjb.org

introduce more product innovation because this had the highest effect of process innovation on financial performance.

Wangui and Muturi (2016) did a study on the financial factors affecting performance of deposit taking savings and credit co-operative societies in Kiambu County. The study focused on 14 Sacco's licensed by SASRA the regulatory body in Kiambu County by the end of 2015. The study was based on data from the annual Sacco audited reports covering a period of 5 years between 2011 and 2015. The study found that the financial performance of Saccos was positively affected by dividends and investment policy, while the financial performance was impaired by loan policies. The Commission also recommended that Sacco grant default loans to minimize the failure to perform the loan. In order to expand the investment portfolio to provide a sustained way of paying the dividend, the Sacco can aim to educate its Members to increase their savings.

Ngure(2017) assessed the effect of financial innovations the general performance of SACCOs in Kenya. The Target population was 60 SACCO's in Kirinyaga County as registered by SASRA. Simple standardized random sampling approach was used for the analysis to extract fifty two SACCOs. The study results have shown that financial innovations in Kirinyaga County have a positive relation to the financial performance of SACCOs. Therefore, to enhance financial performance, SACCOs must accept financial innovative products, process innovations and structural innovations. To raise the amount of savings and deposits, SACCOs can bring up new deposit accounts.

\section{Critique of the literature review}

Revathy and Santhi (2008) assessed the financial reengineering effect on State Bank of India. The purpose of this study was to evaluate the state bank's economic performance. This is an indication that the study was narrowed to financial reengineering in the context of one bank in India, State Bank. Despite the findings embracing specificity, the study scope that is outside the State Bank and banking industry is left unaddressed.

Khuzaimah (2011) aimed at assessing the impact of reengineering on corporate performance and finding out how business process reengineering can assist organizations implement innovative and strategic administrative changes in Malaysian Banks. This is a positive finding in relation to financial institutions of banks, and thus the study could have implications too in other contexts. Thus, the current study seeks to extrapolate them to SACCOs in financial sector.

Aregbeyen (2011) focused on the effect of business reengineering on the performance of First Bank in Nigeria. Geographically, the study was based in Nigeria state and thus despite the study giving empirical evidence on the business reengineering practices in banks, the findings were found to be limited in scope and needs extrapolation in order to extend to other neighbouring countries. This was on the basis that the study only limited to a single bank in Nigeria.

Muteke (2015) conducted a research study to examine whether SACCOs ' financial performance in Mombasa County is influenced institutional innovation, process innovation and product innovation. Given the association and share of a lot of characteristics of Kenya and a County (Mombasa) within, the findings of the study provide applicable findings to be embodied. However, there are some economic and political variations between the two geographical measures and limitations which warrants a study to be done specifically in Kenya in order to ascertain the link. 
Wangui and Muturi (2016) likewise conducted a survey on the financial factors affecting performance of deposit -taking savings and credit co-operative societies in Kiambu County. All 14 Sacco's licensed by SASRA the regulatory body in Kiambu County by the end of 2015 was focused in the study. Ngure (2017) also assessed the effect of financial innovations the general performance of SACCOs in Kenya. The population of targets was 60 SACCO's in Kirinyaga County as registered by SASRA. The current study thus identifies that the study has a differing scope and in order to address the problem on a wider scope than individual counties, the current study seeks to fill in the gap.

Revathy and Santhi (2014) did a study in of financial reengineering in Ashok Leyland Ltd in Hosur. Secondary data was collected between year 2009 and 2013 from the financial reports. The unit of analysis was one bank, which cannot be fully ascertained and generalized for all the other banks or financial institutions such as SACCOs. Moreover, the study did not specify on the use of qualitative or quantitative data. This thus indicates that the study lacks robustness and to a great extent it presents channels in narrow findings hard to generalize to other financial institutions.

Likewise, with the help of cross-sectional survey design and stratified methods to evaluate the sample of 30 SACCOs working and active in Nyeri County, Ngure (2017) sought to establish the the effect of financial innovation on the performance of SACCOs.It was noted that as of December 31 , 2013, the population of the study was 56 SACCOs. There still could be a possibility of conducting the census survey in all the SACCOs. Revathy and Santhi (2008) assessed the financial reengineering effect on State Bank of India. The purpose of this study was to evaluate the state bank's economic performance. The secondary analysis data is the Balance Sheet (2008 to 2012). This study did not include the collection of primary data in order to collect the views of the management in the banks concerning financial reengineering.

The study by Shin and Jemella (2002) investigated during this study the most suitable BPR approaches for financial institutions: a case study of Chase Manhattan Bank. The findings were informative in that they addressed Chase Business process reengineering (BPR) projects include four phases involving a broad range of activities. However, the concept of the study somewhat differed from the current study since the goal was generally business process reengineering. Thus, the study failed to focus on the prevalence of financial reengineering. Eniola and Entebang (2015) likewise were concerned on aimed to assess the financing strategies of SME in Nigeria.The article conceptualized their financing challenges, sources of funding, the ways for exploiting innovative ways of improving funding through crowd-funding, and the need to provide an environmental regulatory framework that supports the growth and promotion of SMEs. Empirically, the study offered pathway to how the Small and medium enterprises needs to adopt improved financial practices. However, the findings provided little evidence of how the factors affect the financial performance.

Muteke (2015) conducted a research study to examine whether SACCOs ' financial performance in Mombasa County is influenced institutional innovation, process innovation and product innovation. The study focuses on innovative practices of SACCOs in effort to influence impact the financial performance in the individual SACCOs.The SACCOs in Mombasa County have made great use of all kinds of financial innovation and all have had a positive effect on their financial results. The study, however, doesn't answer the question which practices need to be reinvented on 
and which need to be dropped. Similarly, Wangui and Muturi (2016) researched on the financial factors affecting performance of deposit -taking savings and credit co-operative societies in Kiambu County. The Commission therefore recommends that Sacco grant default loans to minimize the failure to perform the loan. The study assessed the possible factors that influence general performance of SACCOs. This study leaves a conceptual gap financial reengineering strategy that affect financial performance in specific.

\subsection{METHODOLOGY}

\subsection{Steps in Literature Review}

The study adopted a desktop literature review method (desk study). This involved an in-depth review of studies related to financial reengineering and financial performance of SACCOs. Three sorting stages were implemented on the subject under study in order to determine the viability of the subject for research.

\subsubsection{Identification and Searching process}

This is the first stage that comprised the initial identification of all articles that were based on financial engineering and financial performance from various data bases. The search was done generally by searching the articles in the Article title, abstract, keywords. A second search involved fully available publications on the subject of financial reengineering and financial performance of SACCOs.

\subsubsection{Filtration Process}

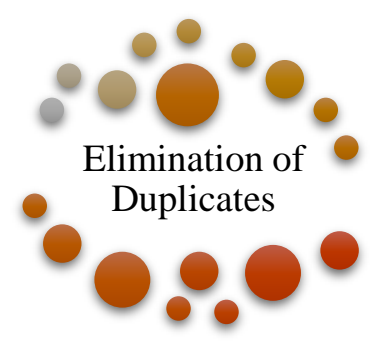

The researcher reviewed the articles to eliminate duplicates; this ensured only unique studies for unique review

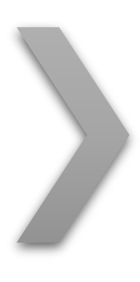

Linguistic check
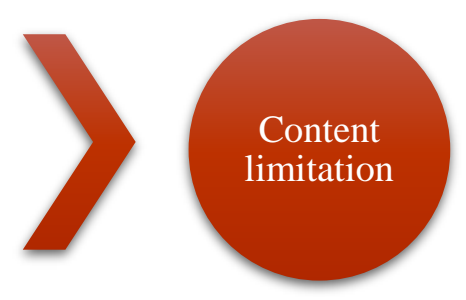

The study took an approach of English literature since it is common globally; thus the focus was on financial reengineering and financial

The selected literature was then performance in English language

\section{Figure 1: Filtration process (by the authors)}

The filtration process was done basing on the currency of the articles (between the year 2014 and 2019). This section indicates the process that the study followed in analysis of the literature. The researcher reviewed the articles to eliminate duplicates; this ensured only unique studies for unique review. The study took an approach of English literature since it is common globally; thus the focus was on financial reengineering in English language. The selected literature was then sorted. 


\subsubsection{Selection Process}

After the filtration was done, the third step involved the selection of fully accessible publications. Reduction of the literature to only fully accessible publications yielded specificity and allowed the researcher to focus on the articles that related to financial reengineering and financial performance which was split into top key words. After an in-depth search into the top key words (financial strategies, financial innovation, financial reengineering, financial performance of SACCOs), the researcher arrived at 12 articles that were suitable for analysis. Analysis was done using Excel where the study presented the findings in form of figure and Tables.

\subsection{FINDINGS AND DISCUSSIONS}

\section{Total Publications by Year}

The study sought to identify the total number of publications done on the subject financial reengineering since the year 2006. The focus was however placed on the year between 2014 and 2019. The findings were presented in the figure below:

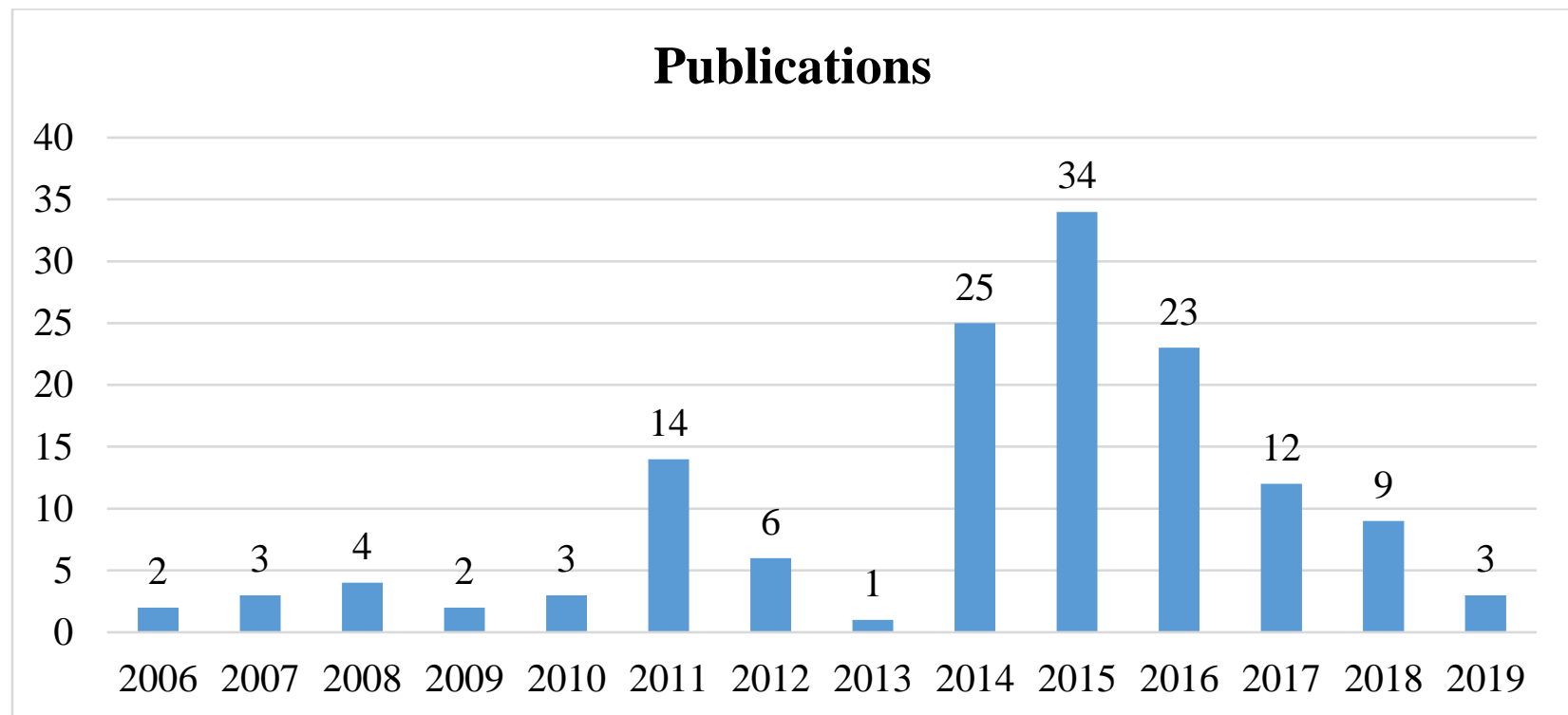

Figure 2: Results from a key word analysis of "financial reengineering" in different data bases (by the authors)

Source: (Survey Data gathered on $7^{\text {th }}$ February 2020).

From the total number of studies reviewed, it was revealed that most of the studies (30) on financial reengineering were done between year 2014 and 2017. Majority of the studies were based between the year 2011 and 2018, implying the relevance of the subject in the near decade.

The study further sought to identify the total number of publications done on the subject financial performance of SACCOs since the year 2006. The findings were presented in the figure below: 


\section{Publications}

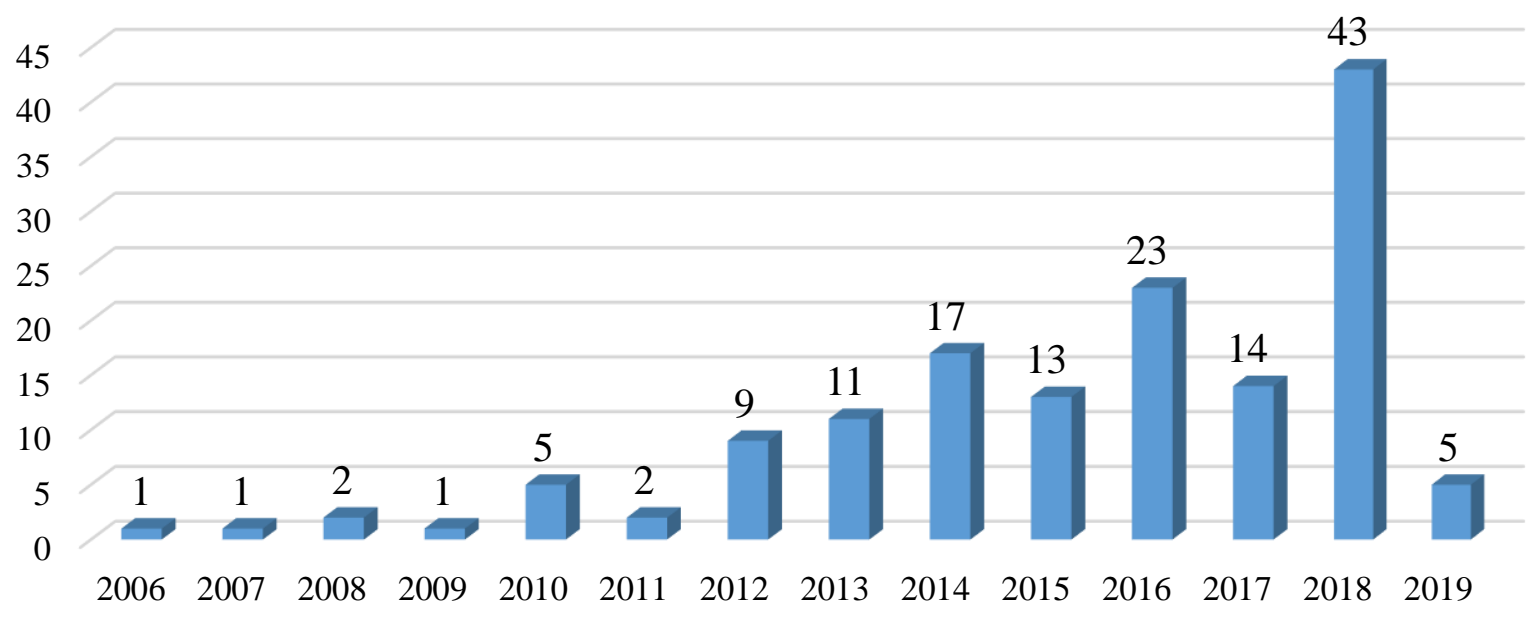

Figure 3: Results from a key word analysis of "financial performance of SACCOs" in different data bases (by the authors)

Source: (Survey Data gathered on $7^{\text {th }}$ February 2020).

From the total number of studies reviewed, it was revealed that most of the studies (43) on financial performance of SACCOs were done in year 2018. Majority of the studies were based between the year 2011 and 2018, implying the relevance of the subject in the near decade.

\section{Number of publications}

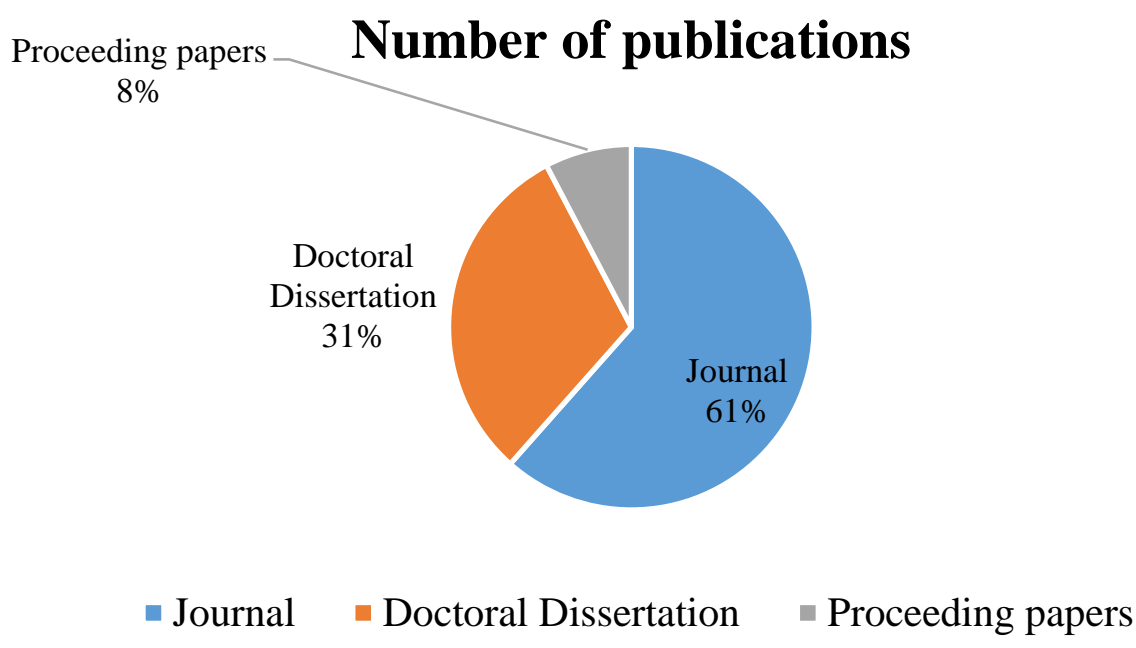

Figure 4: Number of publications

Source: (Survey Data gathered on $7^{\text {th }}$ February 2020) 
From the analysis done on the number of publications done based on the Key words financial reengineering and financial performance, the results indicated that majority of the studies (61\%) were Journal articles published under various journal platforms. In addition, the study underscored that $8 \%$ of them were both proceedings papers and only $31 \%$ of the studies were doctoral dissertation. This is an implication that the studies done on financial engineering and financial performance contributes widely to scientific knowledge of the subject and thus proves to be a viable subject to discuss on.

From the analysis of the relationship between financial reengineering and financial performance of SACCOs, majority of the studies revealed a positive relationship between the variable. The studies by Khuzaimah (2011), Shin and Jemella (2002), Ngure (2017) and Nyathira (2012) revealed a positive relationship. Therefore, financial reengineering has a significant influence on financial performance of SACCOs.

\subsection{CONCLUSION AND RECCOMENDATIONS}

\subsection{Conclusions}

Thus, based on the above findings, the current study concludes that it is relevant and worthwhile for the analysis on financial practice and performance of SACCOs be conducted in African countries in order to extrapolate on the pool of knowledge available. This applies to Kenyan context, since the study noted that there were several knowledge gaps that were left un-addressed. For instance, the conceptual, contextual and methodological gaps.

In addition, the study is warranted to seek to an in-depth analysis on financial reengineering and performance of SACCOs especially in Kenya since the study noted that in Kenya the SACCOs have in the past experienced financial performance negatively. Since the researcher has identified weak focus on the financial reengineering subject and its possible effect on the financial performance of Kenyan SACCOs, there need for a study to be conducted on the study.

Methodologically, since the researcher is convinced of the use of descriptive research design and its applicability to the subject under review, the study is warranted to pursue the same direction in Kenya. In addition, the researcher is at a disposal of the able research instruments and quality data that would provide the analysis an avenue for the study.

\subsection{Recommendations}

Based on the survey, the study recommends the following:

i. This is a maiden study in Kenya that other authors from different research institutes can use to base future studies on.

ii. Findings from this study may be used to shape policy in the area of managing financial performance in SACCOs. Currently, the existing financial strategies are weak, not standard and not competitive since the competition from other related financial institutions is stiff. The findings would help to further develop an adaptive strategy for to step up in the competition in the financial sector. 
International Journal of Accounting and Finance (IJAF)

ISSN 2518 - 4113 (online)

Vol. 5, Issue 1, No. 2, pp 19 - 31, 2020

www.iprjb.org

iii. The findings would help to further develop a monitoring mechanism for the SACCOs in the Kenyan economy to invest in financial reengineering to boost their financial performance.

\section{REFERENCES}

Aregbeyen, O. (2011). Business Reengineering and Organizational Performance in Nigeria: A Case Study of First Bank Nigeria Plc. International business management, 5(3), 151-158.

Batiz-Lazo, B. \& Woldesenbet, K. (2006). The dynamics of product and process innovation in UK banking. International Journal of Financial Services Management, 1 (4), 400-421.

Becheikh, N., Landry, R., \& Amara, N. (2006). Lessons from innovation empirical studies in the manufacturing sector: Technovation. 26(5), 644-664.

Bwana, K. M., \& Mwakujonga, J. (2013). Issues in SACCO development in Kenya and Tanzania: The historical and development perspectives. The International Institute for Science, Technology and Education Journal, 3(5), 14-22.

Coad, A., \& Rao, R. (2008). Innovation and firm growth in high-tech sectors: A quantile regression approach. Research Policy, 37(4), 633-48.

Eniola, A. A., \& Entebang, H. (2015). SME firm performance-financial innovation and challenges. Procedia-Social and Behavioral Sciences, 195, 334-342.

Grundiche, Y. (2004). Marketing Strategy and Plans: Organizational Perspectives, 2nd edition. Chicago: The Dryden Press

Kamonjo, K. L. (2014). Corporate governance practice and its effect on financial performance in SACCOs (A case study of urban SACCOs in Kirinyaga CountyKenya). Nairobi: Kenyatta University

Khuzaimah, A. L. (2011). The impact of business process reengineering on organizational Performance (Doctoral dissertation, Universiti Utara Malaysia).

Kimani, E. M. (2016). Effect of Government Regulations on Factors Hindering Financing of Small Scale Water Investments in Kenya. International Journal of Advanced Engineering and Management Research, 1(2), 70-85.

Maorwe, H. N. (2012). Factors influencing the implementation of strategic plans in savings and credit co-operative societies in Imenti North District-Kenya Unpublished Doctoral dissertation. Nairobi: Kenyatta University.

Muteke, S. M. (2015). The relationship between financial innovation and financial performance among savings and credit co-operatives societies in Mombasa County, Kenya. Unpublished MBA project, University of Nairobi.

Mutuku, B. M. (2014). The Relationship between Financial Innovation and Efficiency of Saccos in Kenya, Unpublished Doctoral dissertation. Nairobi: University of Nairobi.

Ngure, F. (2017). Financial Innovations and Performance of Savings and Credit Co-operatives Societies in Kirinyaga County, Kenya (Doctoral dissertation, University of Embu). 
Njenga, S. M., Kiragu, D. N., \& Opiyo, H. O. (2015). Influence of Financial Innovations on Financial Performance of Savings and Credit Co-Operative Societies in Nyeri County Kenya. European Journal of Business and Social Sciences, 4(06), 88-99.

Nyathira, C. N. (2012). Financial innovation and its effect on financial performance of commercial banks in Kenya (Doctoral dissertation).

Onduko, E. M. (2013). The relationship between financial innovation and financial performance among Savings and Credit Co-operatives Societies in Nairobi County, Kenya, Unpublished Doctoral dissertation. Nairobi: University of Nairobi.

Revathy, M. S., \& Santhi, V. (2014). A Study on Financial Reengineering in Ashok Leyland ltd., Hosur.

Revathy, S., \& Santhi, V. (2008). A Study on Financial Re-Engineering With Particular Reference of State Bank of India, Dindigul. ratio, 9(79400929.18), 2756167-13.

Revathy, S., \& Santhi, V. (2008). A Study on Financial Re-Engineering With Particular Reference of State Bank of India, Dindigul. ratio, 9(79400929.18), 2756167-13.

Shin, N., \& Jemella, D. F. (2002). Business process reengineering and performance improvement. Business Process Management Journal.

Susman, G., Warren, A., Ding, M., \& Stites, J. P. (2006). Product and service innovation in small and medium-sized enterprises. Research Sponsored by United States Department of Commerce-The National Institute of Standards and Technology Manufacturing Extension Partnership.

Terziovski, M., Fitzpatrick, P., \& O’Neill, P. (2003). Successful predictors of business process reengineering (BPR) in financial services. International Journal of Production Economics, 84(1), 35-50.

Wangui, M. M., \& Muturi, W. (2016). Financial Factors Affecting Performance of Deposit Taking Savings and Credit Co-Operative Societies in Kenya: A Case of Kiambu County. 